\title{
Comparative Analysis of the Situation of Ethnic Minorities in Kosovo and the Republic of North Macedonia
}

\author{
Zenun Halili $^{1}$ \\ ${ }^{1}$ University of Prishtina \\ Rr. "George Bush", p. n., 10000 Prishtinë, Republika e Kosovës
}

DOl: $10.22178 /$ pos.52-5

LCC Subject Category: KJE5-7975

Received 28.10.2019

Accepted 28.11.2019

Published online 30.11.2019

Corresponding Author:

zenun.halili@uni-pr.edu

(c) 2019 The Author. This article

is licensed under a Creative

Commons Attribution 4.0 License

(c) (1)

\begin{abstract}
This paper aims at discussing the matter of the national minorities in Kosovo and the Republic of North Macedonia. Role, position and the rights of the national minorities are the key focus of this study. While the Balkan countries and some European countries have had issues with recognizing and supporting the different ethnic communities living within their borders, Kosovo and the Republic of North Macedonia have, since their independence, recognized the existence of different communities as a given fact. Since gaining independence, they have constitutionally guaranteed all citizens freedom of association for the 'accomplishment and protection of their political, economic, social, cultural and other rights and beliefs. Being a geographical part of the Western Balkans, these two countries have been delayed in the European integration process even though their peoples and governments aspire to become part of the European Union. I think that national minorities have an important role in this process because, in the past, these two states have been characterized by a lack of respecting the rights of national minorities. For this reason, both countries have faced a lack of internal stability and conflict with each other as a result of the lack of respect for the rights of respective national minorities.
\end{abstract}

Keywords: Constitution; National Minorities; Constitutional rights; Ahtisaari plan; Ohrid Framework Agreement.

\section{INTRODUCTION}

Kosovo and the Republic of North Macedonia are two countries located in the Western Balkans area, a geographic area in Southeast Europe, where four of the great civilizations of the world have followed each other to produce a dynamic, diverse and versatile local civilization. This region has been a meeting point for the cultures of ancient Greece and Rome, Byzantium, Ottoman Turkey, and Catholic Europe, which clashed and once they merged. The Balkans is a region that no single culture was able to fully dominate [30]. Numerous conquests along with its geography have caused this small region to be inhabited by a large number of peoples which, over the centuries, have been mixed. Because of the imperial wars in the Balkan region, large population movements have taken place, while various religious and cultural influences led to the mix of Catholic and Orthodox Christianity with Islam. This has affected Balkan peoples for thousands of years living within large multi-ethnic states.

The ending of the First World War, along with the ultimate destruction of the multinational em- pires, marked the end of the process of creating national states, but unlike the Western and Central European countries such as Germany and Hungary which represented the best example of the national state [24], in the Balkans, the border-bound policy failed based on the principle of nationality and self-determination. Since borders in the Balkans have been determined arbitrarily, and some of these states, within them, hold several people without their will, the Western Balkans region has faced various conflicts. In such a situation, Albanians were found in Serbia and Macedonia, as well as Serbs in Kosovo. Each of them has aimed at showing the old roots in the Balkans, the origin and the right to own certain territories. To create homogeneous areas, some of the peoples of the Western Balkans have practiced assimilation, expulsion, and exchange of the population. In some areas more and some less, the attempt to assimilate national minorities has been a common practice in Western Balkan countries.

This paper is divided into five sections, which relate to the research question and the hypotheses 
raised. The main question of this research is: What is the position and the rights of national minorities in Kosovo and the Republic of North Macedonia? Whereas the main hypothesis of this research is: 'Does the position of national minorities contribute to the stability of the political situation in Kosovo and the Republic of North Macedonia'? The first part explains the treatment of national minorities according to International Law. The second part analyses the history of the national minorities in Kosovo and the Republic of North Macedonia. The third section tackles the rights of minorities from the constitutional and legal perspective. The fourth section analyses the Progress Reports regarding the position of minorities in Kosovo and the Republic of North Macedonia. The fifth section contains the conclusions of this paper.

\section{METHODOLOGY}

The working methodology for the preparation of this research paper consists of different adequate methods, which are used for research purposes in the social sciences. The comparative analysis method is used to compare the data that was found in different sources, while the descriptive method is used to describe the legality of different processes, events, and circumstances. The other methods which are used to prepare this paper are: Theoretical Analysis Method which is used to explain, predict, and understand the events and developments that are dealt with in this paper, and the statistical method is used to analyze, interpret and report the research findings. The historical method is used to collect the historical information, and the synthesis method, to verify the facts and processes used in this paper.

\section{RESULTS AND DISCUSSION}

\section{Treatment of National Minorities according to the International Law}

The problem of recognizing and protecting the rights of minorities is an early problem, which has been the subject of treaties between states. In the 19th century, the slow rise of contemporary international law began in the West, but the agreements reached during that century did little to protect the rights of minorities. They were aimed at ensuring stability and cooperation at the state level. The problem of equality of nations drew more attention after the bourgeois French revolution. The first recognition and international guarantee of the rights of national minorities were made in the Vienna treaties of 1815, where Russia, Prussia, and Austria agreed to respect the nationality of their Polish citizens [6]. For pragmatic and humanitarian reasons, international law has been a protective instrument, because the issue of minorities has never been entirely incorporated in national legislation. In very few countries around the world, citizens share the same language or belong to the same national group [22]. For this reason, the general international law and customary law recognize the right of states to protect the interests of their people living outside their country.

Throughout history, various efforts have been made to protect cultural minorities and to bring to end possible conflicts between the majority and national minorities. At the beginning of the last century, bilateral treaties regulated the treatment of foreign nationals in other countries. This treaty system has been extended by providing a multilateral basis under the League of Nations mandate. But the treaties were inadequate because a national minority was protected from discrimination and oppression only if there was a 'mother country' that would be interested in them [22]. The problem of the protection of national minorities is also closely linked to the territorial integrity of states. Oftentimes, states are concerned that recognition of minority rights may threaten their territorial integrity. But, within the international community, a consensus has been reached that recognizing minority rights should not question the principle of territorial integrity and national unity of states. Despite the principles of non-intervention and territorial integrity, mother countries have expressed their desire to intervene to ensure the rights of national minorities. In the period between the two world wars, in a few countries efforts have been made to regulate the internal law and ensure the protection of national minorities. Whereas, the League of Nations, as in many other areas, was also powerless in protecting the rights of national minorities.

The end of World War II and the formation of the United Nations opened a door to human rights and their impact on international law [27]. The United Nations Charter, signed in San Francisco on 26 June 1945 by representatives of fifty nations, was the product of an evolutionary devel- 
opment that lasted for many decades, even centuries [15]. But the Charter does not mention minorities in a particular way, instead, it emphasizes individual human rights. The major human rights interest at the San Francisco Conference had not provoked proposals for the protection of minorities, even though the League of Nations agreement did not mention them either. The fact that no amendment favoring the protection of minorities was made, makes it clear that instead, the Charter referred more to human rights related to the principle of non-discrimination.

After the Second World War, the European Convention on Human Rights and Fundamental Freedoms (ECHR) was established to protect human rights and to promote democracy throughout Europe. After it was signed in Rome on 4 November 1950, the Convention entered into force on 3 September 1953 [10]. All member states of the Council of Europe are party to the Convention which established the European Court of Human Rights. The European Convention is still the only international human rights treaty that has provided a high degree of individual protection as it gives the individual an active role in the international arena. The "Framework Convention for the Protection of National Minorities" is the main convention for the international protection of national minorities in Europe. The Framework Convention for the Protection of $\mathrm{Na}$ tional Minorities (Convention) was adopted by the Committee of Ministers of the Council of Europe in 1994 and entered into force in 1998. It is the first legally binding multilateral instrument devoted to the protection of minorities and is regarded as the most comprehensive international standard in the field of minority rights so far. To a large extent, it transforms the political commitments of the 1990 Copenhagen Document of the Organization for Security and Cooperation in $\mathrm{Eu}-$ rope (OSCE) into legal obligations [9].

In the post-Cold War era, a discourse on minority rights has gained legitimacy in international debates. This discourse is analytically reflected in the work of Will Kymlicka [11]. He argues that the international debate on minority rights ended after the Cold War, as minority rights issues are considered not only 'exclusively a domestic affair' of a state but more as international-level issues. At the same time, minority rights and their respect have created new conflicts in the former Yugoslavia, where many minorities already belonged to the new states.

\section{National Minorities in Kosovo and the Republic of North Macedonia}

Republic of Kosovo and the Republic of North Macedonia, have been constituting parts of the former Yugoslavian Federation. But despite being part of the state of Yugoslavia, Albanians and Macedonians did not forget their national identity. Unlike the Republic of North Macedonia, which gained independence in 1991, Kosovo has a different history from all Western Balkan countries. It had a different status from other republics in the former Yugoslav Federation and was the last to get the independence. In Kosovo, relations between the local Albanian minority and the dominant Serbs, a numerical minority in Kosovo but a political majority in then Yugoslavia, were marred by violence throughout the 1990s. The government systematically repressed the Kosovo Albanians, who declared independence, organized parallel institutions, and launched nonviolent civil resistance. In 1998-1999 the conflict escalated to internal warfare and NATO military intervention, the defeat of the Serbian government, and a new period in Kosovo's political development characterized by the rule of the UN Interim Administration Mission in Kosovo (UNMIK) and the presence of NATO peacekeeping forces [20]. During the post-conflict period, the group switched positions. Albanians became a political majority in Kosovo, and Serbs a political minority.

The process of the final status of Kosovo was very difficult. In the years after the war, various international negotiations, as well as less formal mediation efforts, proved unsuccessful in resolving Kosovo's status. 'Violent ethnic rioting in March 2004 compelled the international community to step up these efforts' [31]. After 15 rounds of talks between Kosovo and Serbia delegations, to reach a political solution for Kosovo's status, on 10 March 2007, the Special Envoy of the UN Secretary-General Martti Ahtisaari prepared the Comprehensive Proposal for the Kosovo Status Settlement. Kosovo would declare supervised independence but had to agree to implement the Ahtisaari Package, or at least incorporate it into its law [19]. By the end of December 2007, the European Union, the United States, and Russia were still unable to find a solution to the final status of Kosovo. Nevertheless, on February 17,2008 , the representatives of the people of Kosovo solemnly proclaimed the Independ- 
ence of Kosovo [17]. In June 2008, as Kosovo's constitution took effect, at the same time, Serbs in Northern Kosovo established parallel government institutions. The earlier contradictions between the Serbian and Albanian populations in the post-war period of 1998-1999 became even greater. The no-confidence gap was broadened despite the presence of the international factor and their peace efforts. The status issue and the different perspectives for the past and the common future made coexistence difficult in the new reality. Dominant communities, Albanians and Serbs, with the encouragement of international institutions, had to build a common future with other Kosovo minorities.

According to data from the population and housing census in 2011, Kosovo's population counted $1,739,825$, excluding northern Kosovo, and had the following ethnic composition: 92.2\% Albanians, $1.5 \%$ Serbs, $1.6 \%$ Bosnians, $0.6 \%$ Gorani, 0.5\% Roma, 0.6\% Egyptians, 0.9\% Ashkali 1.1\% Turks and $0.6 \%$ 'Other' or Not Specified [21]. Serbs living in northern Kosovo are the main problem in the country. On the other hand, Serbs living in other parts of the country are more cooperative and have begun to integrate into the new reality of Kosovo. Three religions: Islam, Orthodoxy, and Catholicism, have long coexisted in Kosovo. A large majority of Kosovo Albanians consider themselves, at least nominally, to be Muslim. A minority, about 60,000, are Catholic. Most Kosovo Serbs, even those who are not actively religious believers, consider Orthodoxy to be an important component of their national identity. Nevertheless, despite this essential division of religious activities along ethnic lines, it cannot be said that religion per se was an important contributing factor in the conflict between Serbs and Albanians [18].

The Republic of North Macedonia gained independence in a peaceful path, refusing to engage in wars that were taking place in the former $\mathrm{Yu}$ goslavia. However, during the period of transition and state-building, political, economic and inter-ethnic disagreements appeared. In Macedonia, interactions between the Macedonian majority and the Albanian minority were consistently tense. The Albanians were represented in parliament as early as 1990 and belonged to the governing coalitions since 1992, but their demands to be a constituent people of the state were perpetually ignored [20]. These tensions culminated at the beginning of 2001, with the armed uprising of ethnic Albanians, against Mac- edonia's constitutional order, which ended with a political solution by signing the Ohrid agreement. In the aftermath, inter-ethnic violence significantly decreased and The Republic of North Macedonia became a candidate for EU membership.

According to the latest census in 2002, the total population of North Macedonia was 2,022,547, and it had the following ethnic composition: 64.2\% Macedonians, 25.2\% Albanians, 3.9\% Turks, 2.7\% Romani, 1.8\% Serbs, 0.8\% Bosnians, $0.5 \%$ Aromanians, and $0.9 \%$ other / unspecified. The largest ethnic group was the Macedonians. The second-largest is the Albanians, who are concentrated in the northwestern part of the nation. Estimates indicate a Roma population of up to 260,000 . Up to $65 \%$ of the population follows Orthodox Christianity, with most belonging to the Macedonian Orthodox Church. Other Christian denominations account for $0.4 \%$ of the population. Muslims account for 33\% of the population. Macedonia has the 5th highest proportion of Muslims in Europe. Most of the Muslims in the country are Turks, Roma or Albanians, although there is a small number of Macedonian Muslims [28].

\section{Constitutional and Legal Position of the National Minorities in Kosovo and the Republic of North Macedonia}

One of the characteristics of democracy is 'Majority Leadership and Respect for Minorities'. In every genuine democracy today, majority rule is both endorsed and limited by the supreme law of the constitution, which protects the rights of individuals. Kosovo and the Republic of North Macedonia as two new democratic states have chosen an affirmative approach about national minorities. The Constitution of the Republic of Kosovo provides certain guarantees for communities living in its territory. The status process itself, but also the events that preceded Kosovo's final status, had imposed a fairly privileged position of Communities. The Kosovo Constitution uses the term 'communities and their members' from a different viewpoint, these communities mean 'national minorities' [2]. The basis of the favorable constitutional position of communities in Kosovo is the Ahtisaari plan. The Ahtisaari plan foresaw comprehensive and specific rights for minority communities, which were later incorporated into the Kosovo constitution which entered into force in June 2008 [4]. This plan provides minorities, particularly the Serb minori- 
ty, rights that no other minority enjoys in Europe.

The rights of national minorities in the Republic of North Macedonia have been advanced with the Constitution of 1991, supplemented and amended by constitutional amendments stemming from the Ohrid Agreement. It is considered that with the signing of the Ohrid Agreement, on 13 August 2001, a more significant advancement of the position of national minorities took place. This agreement represents the basis for Macedonia's democratization and a compromise on the fundamental rights and freedoms of national minorities in the country [3]. The Constitution of the Republic of Kosovo in its third chapter has foreseen a special system of the position of ethnic, religious and cultural groups, which are recognized as communities in the constitutional system of the Republic of Kosovo.

Article 57, of the Constitution of Kosovo, contains some general principles of the rights of communities and their members. The special status of communities and their special position is thus seen in the first paragraph of this article which states that "communities enjoy special rights outlined in the constitution, in addition to the freedoms and human rights that the Constitution of the Republic of Kosovo has foreseen in the second chapter' [7]. Annex II (Article 3) of the Ahtisaari plan provides the communities and their members with the right to express, preserve and develop their language and culture, receive pre-school, elementary and secondary public education in their languages, to establish and maintain their publicly funded private schools, to expose their national symbols and to have their media [29]. One of the special commitments of the Republic of Kosovo is the protection of the cultural and religious heritage of communities. The legal language used in Article 58, Paragraph 5 of the Constitution of Kosovo implies this commitment. Paragraph 14 of Article 59 of the Constitution of the Republic of Kosovo has provided for the right of communities to establish associations of culture, art, science and other associations that serve communities in the preservation and promotion of their culture. The official languages in the Republic of Kosovo are Albanian and Serbian. The Turkish, Bosnian and Roma languages have the status of official languages at the municipal level.

The Macedonian people have been and continue to be aware that for centuries in its territory in
North Macedonia they have lived and continue to live together with other nationalities, of which the Albanian and Turkish nationalities are most numerous [23]. The rights of national minorities in Macedonia are defined by the constitution and the law. The Constitution of the Republic of Macedonia in its Article 9 guarantees that 'Citizens of the Republic of Macedonia are equal in their freedoms and rights, regardless of gender, race, the color of skin, national and social origin, political and religious conviction, property and social status. Citizens are equal before the Constitution and the law'. In its Eighth Amendment, the Macedonian Constitution guarantees members of national minorities the right to cultivate and develop their identity and the use of national symbols. The Constitution guarantees all minorities the protection of ethnic, cultural, linguistic and religious identity [8]. As in Kosovo, national minorities in Macedonia have the right to establish cultural, artistic, educational and scientific associations. The right of national minorities to learn in their mother tongue is determined by law. Article 19 of the Constitution guarantees freedom of religion. In the entire Republic of North Macedonia, the official language is Macedonian. Any other language spoken by at least 20 percent of the population is also an official language, as defined by law.

\section{Representation of national minorities in public life and decision-making}

Citizens belonging to different communities in Kosovo have the right to form political parties and to run for positions and posts at all levels of government. In Kosovo, there is a large number of political parties registered and fortunately, all communities are represented by one or more parties [16]. The Constitution of the Republic of Kosovo has provided a commodity about the participation of communities in public life and decision-making. Such participation is especially noticed in the legislative, executive and judicial powers. The Assembly of the Republic of Kosovo, as the bearer of the sovereignty of the people, is the body in which the communities living in Kosovo are represented. Communities are represented in the chairmanship and assembly committees. Of all the members of the Presidency of the Assembly of the Republic of Kosovo, a member is from the Serb community and a member of other communities [1]. 
The Constitution of North Macedonia (1991) has laid the foundations for building a new political, economic and legal development of the Republic as a sovereign and independent state. It is important that among the fundamental values of the constitutional order of the Republic of Macedonia are set the political pluralism, free democratic elections and the division of state powers into legislative, executive and judicial [8]. The division of state power increases the efficiency of the judicial system, creating the legal basis for each institution to carry out its activity in an independent manner. This affects the strengthening of the rule of law and respect for the fundamental freedoms and rights of citizens. In this regard, the issue of adequate representation of representatives of national minorities, in all public institutions and bodies of state power is of special importance. According to Article 23 of the Constitution, every citizen of the Republic of Macedonia has the right to participate in the performance of public duties. As in Kosovo, Sovereignty in the Republic of Macedonia derives from the citizens and belongs to the citizens. Based on Article 2 of the Constitution, the citizens of the Republic of North Macedonia exercise their authority through democratically elected Representatives, through referendum and other forms of direct expression.

Political representation of communities in the Assembly of Kosovo is also done through reserved seats or guaranteed seats. Reserved or guaranteed seats are the most unique way of representing communities in the constitutional system of the Republic of Kosovo. This mode of representation was designed in the Ahtisaari plan, which constitutes a rare practice of representing a particular ethnic, religious or cultural group [29]. Out of 120 seats in the Assembly of the Republic of Kosovo, 20 of them are reserved or guaranteed for the communities. Serbian representatives are guaranteed 10 seats, Roma, Ashkali and Egyptian communities are guaranteed four seats, Bosnians three, two Turks, and one for Gorani representative. About this way of community representation, it is also interesting how the community's decision-making in the Assembly is concerned. Communities use the socalled double majority or that of Badinter, when it comes to assembly decisions that directly affect the interests of communities, including so-called vital legislation. Most of Badinter or most of the double voting is also used in the Assembly of the Republic of North Macedonia when it comes to the adoption of laws related to the use of language, culture, personal documents, education and the use of symbols. For every minorityrelated decision and their members, two-thirds of the votes of all MPs are required, and the majority of the votes of MPs who belong to minorities that are not in the majority in Macedonia. This constitutional mechanism emerged from the 2001 Ohrid Agreement, which is the basis for the democratization of Macedonia and the preservation of the multi-ethnic character of the state.

Another important level of community representation in the Republic of Kosovo is the representation of minorities in executive power. Guarantees for such representation, as well as in the Assembly, have emerged from the Ahtisaari plan, which in Articles 5.1 and 5.2 of Annex 1 provides for the representation of communities at the level of ministers and deputy ministers. Article 96 of the Constitution of Kosovo also regulates the division of power for communities into state executive bodies, while the Kosovo government is obliged to have a composition involving minority parties. According to Article 96 of the Constitution, the Serb community must be represented by one minister, and that one minister must be appointed from another minority community; a third minister from a minority community can also be appointed if the Kosovo government has more than 12 ministries. The Serb community is politically superior and dominates with their political superiority about other communities. In December 2008, the Government of the Republic of Kosovo approved the Strategy for the Integration of Roma, Ashkali and Egyptian Communities in the Republic of Kosovo 2009-2014, as well as the Action Plan for its implementation, but despite guaranteed representation through reserved seats in Kosovo's key legislative and executive bodies, Roma, Ashkali and Egyptian communities in Kosovo are among the most discriminated, poorest, and most vulnerable communities in Kosovo society.

In addition to declaring independence, Macedonia started the democratic transition, implementing a multi-party system and pluralistic elections. Unlike Kosovo, where Albanians during the years of occupation did not participate in the elections that the Serbian government organized in Kosovo, in the Republic of Northern Macedonia, Albanian political entities participated in elections and government structures alongside numerous Macedonian parties. Macedonia has been governed by broad coalitions including Macedonian 
and Albanian parties, as well as occasionally parties of other smaller minorities, since the first free elections in 1991. This system of government formation, not a constitutional requirement, but a tradition that has developed since the end of one-party rule, has not been directly affected by the Ohrid Agreement [5]. The pure multi-ethnic composition is also reflected in the Justice System in Kosovo and Macedonia. In the entire judicial system of the Republic of Kosovo, the maximum participation rate of non-majority communities is 15 percent. This norm of representation, except in the Ahtisaari Package, is standardized in the Constitution of the Republic of Kosovo [7]. The Constitutional Court of the Republic of Kosovo, as a body for the protection of the constitution, includes in its composition non-majority communities. Out of a total of nine judges, two of them belong to communities.

The Republic of Macedonia, since its independence, has made considerable efforts to improve the position of the nationalities in various areas. The nationalities are also represented in the judiciary: in the Constitutional Court, three of the nine members, and in the Judicial Council of the Republic, two of the seven members, belong to nationalities. In the basic courts, $87 \%$ of the 477 elected judges are Macedonians, 6.9\% are Albanians, $2.5 \%$ are Vlachs, $1.8 \%$ are Serbs, $0.6 \%$ are Turks and Muslims each, and $0.8 \%$ belong to other nationalities. In the courts of appeal, 84\% of the 88 elected judges are Macedonians, 9.1\% are Albanians, $2.2 \%$ are Turks and Serbs, and $1.14 \%$ are Vlachs and other nationalities. In the Supreme Court of the Republic of Macedonia, four of the 25 judges are Albanians and one member is of the Vlach nationality [25].

In both countries, national minorities are represented in all institutions and levels of government. Representation in local government bodies is a very important mechanism for realizing community rights both in Kosovo and in Macedonia. Local Governance in the Republic of Kosovo is regulated by the Constitution, giving all citizens of Kosovo the right to representation in local government. It should be mentioned that local government, especially the decentralization process, is one of the issues dealt with in the Ahtisaari Package. This document emphasizes that "Local Self-Government in Kosovo will be based on the principles of good governance, transparency, efficiency and effectiveness in the delivery of public services, paying particular attention to the needs and concerns of the non- majority communities and their members" [29]. Power-sharing among various ethnic groups in the society of Macedonia started after the 2001 conflict and with the OFA agreement. There was a municipality restructuring in August 2004, which was supposed to serve as a mechanism that would allow Albanians and other ethnic groups to have more decentralized power in exercising their duties and rights [26]. Ahtisaari's Package and the Ohrid Agreement have created the basis for minority representation in the police, army and intelligence services. Viewed comparatively, Kosovo stands better than Macedonia in this regard.

Communities in Kosovo except in other bodies are also represented in the Presidency of the Republic of Kosovo. This representation is achieved through the Community Consultative Council acting under the authority of the President of the Republic. This council is made up of representatives of various associations of communities living in Kosovo. The mandate and scope of the consultative council for communities are defined by the Constitution of the Republic of Kosovo in Article 60 . We encounter a representation of this nature in the Republic of North Macedonia. Following the Constitution, the Assembly of the Republic of Macedonia establishes a Council for Inter-Ethnic Relations to be composed of the following: the President of the Assembly and two members representing Macedonians, Albanians, Turks, Vlachs, Roma, respectively and two members representing other national minorities. Similar commission on Inter-Ethnic Relations, by the Law on Local Self- Government, could be established within the Council of the unit of the local self-government [8].

\section{Progress Reports regarding the position of minorities in Kosovo and the Republic of North Macedonia}

While North Macedonia's accession to the European Union (EU) has been on the current agenda for future enlargement of the EU since 2005, Kosovo is recognized by the $\mathrm{EU}$ as a potential candidate for accession. Being the last state from the Balkan Peninsula, in 2015, Kosovo signed with EU Stabilization and Association Agreement [12]. Although among the countries of the Western Balkans, Kosovo has the most mechanisms focused on the rights of non-majority communities, both at the central and local level, the launching of its membership process in the European Union 
offers stronger guarantees for respect of human rights and freedoms, as well as the rights of minority communities.

According to the politicians and their population, Kosovo and the Republic of North Macedonia are determined to fulfill the Copenhagen Criteria and other conditions that candidate countries must meet before they can become members of the European Union. To understand the fulfillment of these criteria, the European Commission publishes the Annual Progress Reports for Western Balkan Countries. Let us present and analyze some of the findings of the European Commission Progress Reports on the Situation of National Minorities in Kosovo and the Republic of North Macedonia.

The 2018 EU Commission Progress Report, which measures progress in Kosovo across a range of areas, does not speak in terms of minority rights but human rights. The legal framework of Kosovo broadly guarantees the protection of human and fundamental rights in line with European standards.

However, according to the 2018 Progress Report, "additional efforts are needed regarding enforcement, Implementation of human rights strategies and legislation is often undermined by inadequate financial and other resources, particularly at the local level, limited political prioritization and lack of coordination" [13].

The Progress Report, states 'that more needs to be done to effectively guarantee the rights of persons belonging to minorities, including Roma and Ashkali and displaced persons, to ensure gender equality in practice, and to advance the protection of cultural heritage'. As in Kosovo, in the Republic of North Macedonia too, the legal framework is broadly in line with European standards. According to the 2018 Progress Report on Macedonia, 'the reforms have been undertaken to enhance compliance with European human rights standards'. The Progress Report states that 'the country took an important step towards its gradual alignment with EU standards in the area of fundamental rights by becoming an observer in the Fundamental Rights Agency'.

'The country worked towards upgrading the legislative framework for nondiscrimination and started creating the legal conditions for establishing an external oversight mechanism of the police. However, there is a need to ensure legal follow-up of cases of hate crime and hate speech, to counter gender stereotyping and strengthen the bodies involved in protecting and promoting human rights' [14].

The Report concludes that 'the implementation of human rights standards and policy documents continue to affect primarily the most vulnerable and marginalized groups in society, including persons with disabilities and Roma'.

Referring to the 2019 European Commission Progress Reports for Kosovo and the Republic of North Macedonia, some positive movement has been noticed regarding minority rights. The Progress Report further emphasizes that 'Kosovo has an adequate institutional and legal framework for the rights and protection of minorities, including relevant strategies and action plans, but implementation remains weak'. 2019 Report further states that:

'Greater coordination is needed at both central and local levels in support of minority communities. To promote a lasting inter-ethnic co-existence, the government needs to step up its efforts to create the conditions for minority communities fully to exercise their rights. They continue to face challenges regarding a secure environment, regaining and accessing the property, civil registration, being able to use their language, adequate provisions for education, employment opportunities and social welfare'.

Regarding security issues, the 2019 European Commission Progress Report for Kosovo, finds that the overall security situation for minority communities remains stable. Nevertheless, according to the report, 'there are recurring incidents of property and livestock theft, which frequently affect Kosovo Serbs, as well as other minority communities. Such incidents, even when they are not ethnically biased, negatively influence the security perceptions of the affected community'. As far as the position of other minorities is concerned, the 2019 Progress Report, concludes that:

'The situation of the Roma and Ashkali communities remains challenging and, in spite of efforts, they still suffer from marginalization and discrimination, with women particularly affected. The poverty levels of these communities remain high compared to other communities in Kosovo'.

Furthermore, according to this report, compared to the previous situation, some improvements can be noted in the field of education. The Progress Report states that 'The Ombudsperson In- 
stitution of Kosovo continued to advance its mandate in promoting, protecting and upholding fundamental rights and freedoms for all and to strengthen its capacity to review cases'. The 2019 Progress Report indicates that North Macedonia has continued to maintain a steady pace of implementation of EU reforms throughout the reporting period. Regarding the protection of minorities, the 2019 Progress Report finds that:

'Work is ongoing to strengthen the legal framework on minorities in non-majority communities. The Parliament adopted the law enabling the establishment of a new Ministry of Political System and Inter-Community Relations. This Ministry would take over the functions of the Secretariat for the Implementation of the Ohrid Framework Agreement and directorates dealing with 32 communities' issues under the Ministry of Education and Science and the Ministry of Culture' rights'.

While the government shows commitment to the integration of all people, including through the work initiated on the drafting of a strategy under the motto 'One society for all', The report further states 'more work needs to be done on improving social cohesion'. The Progress Report finds that 'There is no system to monitor the implementation of the recommendations issued by the Advisory Committee of the Framework Convention on National Minorities, and existing measures, mainly funded by donors, are insufficient'. Regarding the position of the Roma community, which is considered to be the most discriminated minority in both Kosovo and North Macedonia, the 2019 Progress Report for North Macedonia finds that:

'Implementation of the Roma inclusion strategy (2014-2020) and corresponding action plans for education, employment, housing and gender, and health, is gradual and much remains to be done on Roma inclusion. The government is committed to continuously increasing funding for Roma integration policies, but the lack of expenditure monitoring, combined with the poor absorption of existing funds, remains a problem'.

According to a regional survey on Roma inclusion, the country has fared well compared to its neighbors, but even despite this, the Progress Report indicates that 'Segregation in school remains high, with $40 \%$ of marginalized Roma students attending majority Roma schools'. The 2019 Progress Report further finds that 'Regarding housing, the objective to reduce the gap be- tween Roma and non-Roma citizens is progressing very slowly and most of the planned measures have not been implemented'. In the concluding part of the Progress Report on the position of marginalized minorities in the Republic of North Macedonia, it is stated that 'Systematic, rather than reactive measures by state institutions are required to address the concerns of Roma and other minorities'.

\section{CONCLUSIONS}

In conclusion, we can say that the problem of national minorities in Kosovo and North Macedonia has been a permanent problem as it has been in other Western Balkan countries. In these countries, efforts have always been made to refrain from accepting the existence of minorities or to minimize the number of national minorities. During the creation of the national state, the national minorities became 'an obstacle' and consequently communities belonging to these minorities suffered, faced displacement, and assimilation.

Recognizing the extreme Balkan nationalism system, political classes in Kosovo and the Republic of North Macedonia have over time realized that non-respect of respective national minorities has had negative consequences for their countries. Therefore, both countries have chosen affirmative approaches to national minorities, providing certain constitutional and legal guarantees for the communities living in their territory. Many of the problems of national minorities in Kosovo and North Macedonia have been caused by the lack of political will and fears that national minorities may have territorial claims and separatist tendencies.

The lack of will and deaf ears for minority rights has brought the opposite reaction in comparison to what the authorities have wanted. The stubbornness to hear the voice of Kosovo Albanians brought to the armed clash between them and Serbia, the clash that led to NATO intervention and independence of Kosovo. The same situation was repeated in North Macedonia, where Macedonian authorities felt frightened by the unconvincing idea that granting more rights to Albanians would bring their demands for detachment. This approach was wrong because the Albanians by their representatives made it clear that they did not demand the dissolution of Macedonia, but only its reformation and equal status with the Macedonians. The economic and political perse- 
cution and persecution of the national minorities in the Republic of North Macedonia as well as in Kosovo did not weaken their efforts to gain more rights but strengthened them. Thus, it must be understood that the idea of the separation of national minorities does not depend solely on the will of the minority, but also the conduct of the majority and the central government. States that do not find common ground with minorities will always face objections coming from national minorities, which may escalate to violent opposition from dissatisfied minorities. Kosovo and the Re- public of North Macedonia are examples in this aspect.

Democratization and respect for national minorities can help in preventing violent conflicts in divided societies, as is also shown by the study of the two cases we have dealt with in this paper. However, throughout Kosovo and the Republic of North Macedonia, much remains to be done to implement the Ahtisaari Package and Ohrid Framework provisions, which guarantee the progress of the rights of national minorities and the democratization of these two countries.

\section{REFERENCES}

1. Assembly of the Republic Kosovo. (2010). Rregullorja e punës së Kuvendit të Kosovës. Retrieved from http://www.kuvendikosoves.org/Uploads/Data/Files/6/Rr_K_RK_29_04_2010_1_EDbu8aqXYd. pdf

2. Bajrami, A. (2011). Sistemi Kushtetues i Republikës së Kosovës. Prishtinë: Kolegji AAB.

3. Bajrami, A., Halili, Z., Zejneli, J., \& Muçaj. F. (2015). Pozita Kushtetuese dhe Ligjore e Pakicave Kombëtare: Aspekte Krahasuese. Prishtinë: Artini.

4. Beha, Adem. (2014). Minority Rights: An Opportunity for Adjustment of Ethnic Relations in Kosovo? Journal on Ethnopolitics and Minority Issues in Europe, 13(4), 85-110.

5. Bieber, F. (2005). Partial Implementation, Partial Success: The Case of Macedonia. In D. Russell, \& I. O'Flynn (Eds.), New Challenges for Power-Sharing: Institutional and Social Reform in Divided Societies (pp. 107-122). London: Pluto.

6. Chászár, E. (1999). The International Problem of National Minorities. Buffalo: Mathias Corvinus Publishing.

7. Constitution of the Republic of Kosovo (Republic of Kosovo), 15.06.2008. Retrieved October 1, 2019, from https://bit.ly/2SS9uAt

8. Constitution of the Republic of North Macedonia (Republic of North Macedonia), 11.01.2019. Retrieved October 1, 2019, from www.sobranie.mk/the-constitution-of-the-republic-ofmacedonia.nspx

9. Council of Europe. (1995 February). Framework convention for the protection of national minorities and explanatory report. Retrieved from https://rm.coe.int/16800c10cf

10. Drzemczewski, A. (1983). European Human Rights Convention in Domestic Law: A comparative study. Oxford: Clarendon Press.

11. Ekonomia. (n. d.). Të Drejtat e Pakicave: Mundësi për Rregullimin e Marrëdhënieve Etnike në Kosovë? Retrieved October 1, 2019, from http://ekonomia-ks.com/?page=1\%2C20\%2C360250

12. European Commission. (2015). Stabilisation and association agreement between the European Union, of the one part, and Kosovo, of the other part. Retrived from https://ec.europa.eu/neighbourhood-enlargement/sites/near/files/news_corner/news/newsfiles/20150430_saa.pdf

13. European Commission. (2019). Kosovo 2019 Report. Retrieved from https://ec.europa.eu/neighbourhood-enlargement/sites/near/files/20190529-kosovoreport.pdf 
14. European Commission. (2019). North Macedonia 2019 Report. Retrieved from https://ec.europa.eu/neighbourhood-enlargement/sites/near/files/20190529-northmacedonia-report.pdf

15. Goodrich, L., Hambro, E. (1949). Charter of the United Nations: Commentary and Documents (2nd ed.). Boston: World Peace Foundation.

16. Gruda, Z. (2001). Mbrojtja Ndërkombëtare e të Drejtave të Njeriut. Prishtinë: Universiteti i Prishtinës.

17. Halili, Z. (2018). State Building Challenges and the European Integration Process: The Kosovo Case. Eastern European Journal of Regional Studies, 4(2), 4-17.

18. International Crisis Group. (2001, January 31). Religion in Kosovo. Retrieved from https://www.crisisgroup.org/europe-central-asia/balkans/kosovo/religion-kosovo

19. Judah, T. (2008). Kosovo: What Everyone Needs to Know? Oxford; New York: Oxford University Press.

20. Koinova, M. (2013). Ethnonationalist conflict in postcommunist states: varieties of governance in Bulgaria, Macedonia, and Kosovo. Philadelphia: University of Pennsylvania Press.

21. Kosovo Agency of Statistics. (2011). Estimation of Kosovo Population 2011. Retrieved from http://ask.rks-gov.net/media/2129/estimation-of-kosovo-population-2011.pdf

22. Kymlicka, W. (2003). Multicultural citizenship: a liberal theory of minority rights. Oxford: Clarendon Press.

23. Lumani, F. (2014). E Drejta Kushtetuese. Tetovë: IRIS.

24. Macartney, C. A. (1968). National States and National Minorities. New York: Russell\& Russell.

25. Ortakovski, V. (2001). Interethnic Relations and Minorities in the Republic of Macedonia. Southeast European Politics, 2(1), 24-45.

26. Sejdini, M. K. (2016). An Overview of the Reformed Local Government in Macedonia. Business and Economic Research, 6(1), 440. doi: 10.5296/ber.v6i1.9350

27. Stearns, P. (2012). Human Rights in World History. New York: Routledge.

28. The State Statistical Office of the Republic of North Macedonia. Population Census. Retrieved from http://www.stat.gov.mk/OblastOpsto_en.aspx?id=31

29. United Nations. (2007, March 26). Comprehensive Proposal for the Kosovo Status Settlement. Retrieved from https://reliefweb.int/sites/reliefweb.int/files/resources/1DC6B184D02567D1852572AA0071 6AF7-Full_Report.pdf

30. Wachtel, A. (2008). The Balkans in World History. New York; Oxford: Oxford University Press.

31. Weitz, R. (2011). War and Governance: International Security in a Changing World Order. Santa Barbara: Praeger. 